\title{
Farklı Yağ Oranına Sahip Keçi Sütü Tozlarının Fizikokimyasal Özellikleri, Toz Akış Davranışı ve Partikül Boyutu Parametrelerinin Belirlenmesi
}

\author{
Durmuş Sert ${ }^{1}$, Emin Mercan ${ }^{2 *}$ \\ ${ }^{I}$ Necmettin Erbakan Üniversitesi, Mühendislik Fakültesi, Gıda Mühendisliği Bölümü, Konya, Türkiye \\ ${ }^{2}$ Bayburt Üniversitesi, Mühendislik Fakültesi, Glda Mühendisliği Bölümü Bayburt, Türkiye

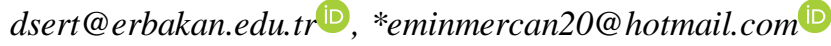 \\ Makale gönderme tarihi: 20.05.2021, Makale kabul tarihi: 22.06.2021
}

\begin{abstract}
Öz
$\mathrm{Bu}$ çalışmada, farklı yağ oranlarının keçi sütü tozunun bazı fizikokimyasal özellikleri, toz akış davranışları (kekleşme, kohezyon ve hıza bağlı toz akış özellikleri) ve partikül boyutu üzerine etkisi incelenmiştir. Bu amaçla yağsız ve yağlı keçi sütü tozu püskürterek kurutma yöntemiyle üretilmiştir. Sıkıştırılmış yığın yoğunluğu yağsız örnekte $0.71 \mathrm{~g}$ $\mathrm{cm}^{-3}$, yağlı örnekte ise $0.57 \mathrm{~g} \mathrm{~cm}^{-3}$ olarak belirlenmiştir. Her iki örneğinde çözünebilirliği \%99.80'dir. Yağsız süt tozunun kekleşme kuvveti $(-0.190$ N.mm) yağl süt tozuna $(26.734$ N.mm) kıyasla oldukça düşük bulunmuştur. Yağsız örneğin kohezyon indeksi 21.7, yağlı örneğin ise 42.2 olarak saptanmıştır. Artan hıza bağlı kohezyon indeksi değerlerinin yağsız süt tozunda yağlı süt tozuna kıyasla daha düşük olduğu tespit edilmiştir. Her iki örneğin de sıkıştırma katsayıları artan hıza bağlı olarak azalmıştır. $100 \mathrm{~mm} \mathrm{~s}^{-1}$ hızda, yağsız süt tozunun sıkıştırma katsayısı $38.6 \mathrm{~N} . \mathrm{mm}$ iken yağlı örnekte bu değer 63.3 N.mm'dir. Yağsız keçi süt tozunda $\mathrm{D}[4,3]$ değeri $44.0 \mu \mathrm{m}$, yağlı örnekte ise $34.2 \mu \mathrm{m}$ olarak tespit edilmiştir. Toz akış analizlerinin sonuçları, keçi sütü tozunun akış davranışı hakkında önemli veriler ortaya koymuştur.
\end{abstract}

Anahtar kelimeler: Fizikokimyasal özellikler, keçi süt tozu, partikül boyutu, toz akış karakteristiği

\section{Determination of Physicochemical Properties, Powder Flow Behavior and Particle Size Parameters of Goat Milk Powders with Different Fat Content}

\begin{abstract}
In this study, the effects of different fat ratios on some physicochemical properties, powder flow behavior (caking, cohesion and powder flow speed dependent properties) and particle size of goat milk powder were investigated. For this purpose, skim (SMP) and whole goat milk powders (WMP) were produced by spray-drying method. The tapped bulk density was determined as $0.71 \mathrm{~g} \mathrm{~cm}^{-3}$ in the SMP and $0.57 \mathrm{~g} \mathrm{~cm}^{-3}$ in the WMP. The solubility in both samples was $99.80 \%$. The caking strength of SMP $(-0.190 \mathrm{~N} . \mathrm{mm})$ was found to be significantly low compared to that of WMP (26.734 N.mm). The cohesion index of SMP was found to be 21.7, and that of the WMP was 42.2. Depending on the increasing speed, cohesion index values were found to be lower in SMP compared WMP. In both samples the compression coefficients decreased with increasing speed. At a speed of $100 \mathrm{~mm} \mathrm{~s}^{-1}$, the compression coefficient of SMP was 38.6 N.mm, while this value was 63.3 N.mm for WMP. The D[4,3] value was determined as $44.0 \mu \mathrm{m}$ in SMP and $34.2 \mu \mathrm{m}$ in WMP. The results of powder flow analysed revealed that crucial data on the flow behavior of goat milk powder.
\end{abstract}

Keywords: Physicochemical properties, goat milk powder, particle size, powder flow characteristic

\section{GíRIŞ}

Dünya genelinde inek sütü dışında süt üretimi, y1lda 133 milyon ton ile toplam üretimin \%17'sinden fazlasını oluşturmaktadır. Bunun \%13.5'i inek sütü haricindeki üretime en büyük katkı sağlayanlardan biri olarak kabul edilen keçi sütü üretimidir (Ranadheera, Naumovski ve Ajlouni, 2018). Mevcut dünya keçi sürüsünün yaklaşık 780 milyon olduğu tahmin edilmekte ve yılda yaklaşık 12.2 milyon ton keçi sütü üretilmektedir. Bu üretim, süt endüstrisinin tüm dünya üretiminin yaklaşık \%2'sine tekabül etmektedir. Keçi sütü ya doğrudan tüketilmekte ya da çeşitli süt ürünlerinin üretiminde kullanılmakta olup 
dünya genelinde önemli sayıda insan keçi sütü ve ürünlerini tüketmektedir (Pulina ve ark., 2018).

Keçi sütü, alkalinite, tamponlama kapasitesi ve sindirilebilirlik açısından sığır ve insan sütünden ayrılır. Aynı zamanda insan sağlığına ve beslenmesine potansiyel olarak yararlı kılan bazı faydalı özelliklere sahiptir (Slačanac ve ark., 2010). Keçi sütü ürünlerinin besin bileşimi inek sütü ürünleriyle karşılaştırılabilir düzeydedir. Bununla birlikte, inek sütü alerjisi olan çocukların diyetlerinde inek sütü ürünlerinin potansiyel ikame maddesi olarak kullanılabilmektedir (Pandya ve Ghodke, 2007).

Keçi sütü; ticari veya geleneksel yöntemlerle popüler peynir çeşitleri ve yoğurdun yanı sıra pastörize içecek, UHT süt, koyulaştırılmış süt, dondurma, süt tozu, geleneksel keçi sütü ürünleri, hatta sabunlar, losyonlar ve tatllların üretiminde kullanılmaktadır. Keçi sütünden üretilen dondurma, sütlü içecek ve süt tozu gibi ürünler besleyici ve antialerjenik özelliklerinden dolayı çocuklar, gençler ve hastalar açısından faydalı bir alternatif süt ürünü olabilmektedir (Pandya ve Ghodke, 2007).

Peynir yapımında keçi sütü kullanımı yaygın olmasına rağmen, keçi sütünün süt tozu üretiminde kullanımı ile ilgili literatürde az sayıda çalışma bulunmaktadır. Bunun muhtemel nedeni küçük çiftliklerden fazla miktarda keçi sütü temin edilememesi ve keçi sütünün inek ve manda sütü ile karıştırılması nedeniyle yetersiz olmasıdır (Ranadheera ve ark., 2019). Reddy ve ark. (2014) tarafından Osmanabadi keçi sütünden yağlı süt tozu üretiminde farklı sicaklik ve konsantrayon uygulamasının etkisi araştırılmışıı. Yapılan farklı bir çalışmada, püskürterek kurutma öncesi soya lesitini ilavesinin keçi süt tozunun fizikokimyasal özelliklerine etkisi incelenmiştir (Fonseca, Bento, Quintero, Gabas ve Oliveira, 2011). Başka bir çalışma ise sade ve farklı konsantrasyonlarda tarçın, keçiboynuzu ve zencefil tozu içeren keçi sütü tozu üretiminin kalite özellikleri üzerine etkisini ele almıştır (Baykal, Karais, Çalışkan-Koç ve Dirim, 2018).

Süt tozu genellikle raf ömrünü uzatmak için koyulaştırılmış sütten püskürtmeli kurutma yöntemi ile üretilmektedir. Süt tozu, ortam sicaklığında önemli bir bozulma olmaksızın uzun süre muhafaza edilebilmektedir. Ayrıca, taşınması, işlenmesi ve gıda ürünlerinin formülasyonunda kolaylık sağlaması nedeniyle genellikle süt tozları tercih edilmektedir.
Süt tozları, rekonsitiüe veya rekombine süt ürünleri ile firıncilı, şekerleme ve et ürünlerinde kullanılmaktadır. $\mathrm{Bu}$ nedenle, süt endüstrisinde yüksek işlevselliğe ve kaliteye sahip geliştirilmiş süt tozlarının üretimi oldukça önemlidir (Er, Sert ve Mercan, 2019). Pek çok bölgede keçi sütünün genellikle düşük arz hacmi, taşıma ve işleme sorunlarından dolayı süt tozu üretimi oldukça istenen bir durum olabilmektedir.

Taşıma, depolama ve işleme süreçlerinde, süt tozlarının akış özelliklerinde meydana gelen değişimler düşük kaliteli ürün eldesi veya üretimde aksamalara neden olabilmesi nedeniyle oldukça önemli bir özelliktir. Çeşitli toz gıdalarda akış özelliklerini belirlemek için hassas, hızlı ve tekrarlanabilir ölçümler yapabilen otomasyona uygun olmaları nedeniyle toz akış analiz cihazları kullanılmaktadır (Mercan, Sert ve Akın, 2018).

Mevcut literatürde keçi sütü tozlarının toz akış özelliklerini inceleyen ve toz akış özellikleri ile fizikokimyasal özelliklerinin birlikte incelendiği herhangi bir çalışmaya rastlanmamıştır. Bu sebeple, bu çalışmadan elde edilen sonuçların literatürdeki boşluğun doldurulmasina ve endüstriyel uygulamalara katkıda bulunacağı varsayılmaktadır. $\mathrm{Bu}$ çalışmanın amacı potansiyel ticari öneme sahip olan püskürterek kurutulmuş yağsız ve yağlı keçi süt tozlarının kekleşme, kohezyon ve hıza bağlı toz akış özelliklerini belirlemektir. Ayrıca bu tozların fizikokimyasal özellikleri ve partikül boyutu değerlerinin tespit edilmesi amaçlanmıştır.

\section{MATERYAL VE METOT}

\section{Materyal}

Araştırmada kullanılan çiğ keçi sütü yerel bir çiftlikten (Konya) temin edilmiştir. Sütler sağımdan sonra kısa süre içinde süt tozu üretiminin yapılacağ Enka Süt AŞ'ye (Konya) getirilmiştir. Kullanılan keçi sütünün ortalama bileşimi şu şekildedir: \%12.15 kuru madde, $\% 3.25$ yağ, \%3.70 protein (yaş bazlı) ve pH 6.73'tür.

\section{Süt Tozu Örneklerinin Üretimi}

Süt tozu üretimi amaciyla işletmeye getirilen keçi sütüne gerekli kimyasal kontroller (asitlik, $\mathrm{pH}$ ve yağ) yapıldıktan sonra süt süzülmüş ve $63^{\circ} \mathrm{C}$ 'de ön 1sıtmaya tabi tutulmuştur. Ön 1sıtmayı takiben sütün yağ oranı seperatör (GEA Westfalia MSD 350, GEA Westfalia Separator Group GmbH, Oelde, Almanya) 
kullanılarak yağsız süt için maksimum $\% 0.15$ (tozda maksimum \%1.5) ve yağlı süt için \%3.1 (tozda minimum \%26) olacak şekilde ayarlanmıştır. Yağ oranı ayarlanmış sütlere $85^{\circ} \mathrm{C}$ 'de $1 \mathrm{dk}$ pastörizasyon uygulanmıştır. Sonrasında pastörize edilmiş yağsız ve yağlı süt düssen film evaporatör (GEA Wiegand $\mathrm{GmbH}$, Ettlingen, Almanya).yardımıyla yaklaşık $\% 45 \pm 1$ kuru maddeye ulaşıncaya kadar koyulaştırılmıştır. Koyulaştırılma işlemini takiben kurutma aşamasına geçilmiştir. Yağsız ve yağlı keçi süt tozu üretiminde GEA Niro Atomizer (GEA Process Engineering A/S, Soeborg, Danimarka) pilot ölçekli püskürtmeli kurutucu kullanılmıştır. Kurutma esnasında, $180^{\circ} \mathrm{C}$ giriş sıcaklığ $1,70^{\circ} \mathrm{C}$ çıkış sıcaklığ ve $30000 \mathrm{~kg} \mathrm{~h}^{-1}$ hava hızı uygulanmıştır. Püskürterek kurutmada döner atomizer kullanılmıştır. Yağsız ve yağlı keçi süt tozları üretimi takiben yaklaşık 1000'er g olacak şekilde 3 kat kraft kâğıt kaplı polietilen torba ile ambalajlanarak analizlerin yapılacağ 1 Necmettin Erbakan Üniversitesi Gıda Mühendisliği Bölümü (Konya) Laboratuvarlarına getirilmiştir.

\section{Süt Tozlarına Ugulanan Analizler}

\section{Fizikokimyasal analizler}

Süt tozlarının nem içeriği gravimetrik olarak kurutma yöntemiyle belirlenmiş ve \% nem olarak hesaplanmıştır (GEA, 2006a). Örneklerin yağ oranı gerber metodu kullanılarak \%0-35 aralığında ölçüm yapabilen Teichert süt tozu bütirometresinden direkt olarak \% yağ olarak okunmasıya tespit edilmiştir (GEA, 2005). Süt tozlarının protein oranı (\%) Mercan (2019) tarafindan bildirilen metoda göre Kjeltech (Kjeltec-8200, Foss Electric, Danimarka) cihazı ile belirlenmiştir. Örneklerin kül içeriğinin belirlenmesi amaciyla süt tozlarına $525^{\circ} \mathrm{C}$ 'deki kül firınında (Carbolite-AAF 1100, Birleşik Krallık) hiç siyahlık kalmayıncaya kadar yaklaşık 16 saat süreyle yakma işlemi uygulanmıştır (GEA, 2004). Titrasyon asitliği nem oranı \%3.17-3.77 arasında olan süt tozlarından rekonstitüe edilmiş sütlerin (\%10 yağsız kuru madde) $0.1 \mathrm{~N} \mathrm{NaOH}$ ile titre edilmesiyle belirlenmiş ve sonuçlar \% laktik asit (\%LA) cinsinden verilmiştir (GEA, 2006b). pH analizi için süt tozları rekonstitüe (\%10 yağsız kuru madde) edilmiş ve 315i/SET (WTW, Almanya) el tipi $\mathrm{pH}$ metre ile ölçüm yapılmıştır. Örneklerin sıkıştırılmış yığın yoğunluğu belirli hacimdeki süt tozuna belirli sayida vurularak belirlenmiş ve sonuçlar $\mathrm{gr} \mathrm{cm}^{-3}$ cinsinden verilmiştir (IDF, 1995). Süt tozlarının çözünebilirliklerinin belirlenmesinde Amerikan Süt Ürünleri Enstitüsü (ADPI) metodu kullanılmış ve \%çözünebilirlik olarak verilmiştir (ADPI, 2002).

\section{Toz akış analizleri}

Keçi süt tozlarının toz akış özelliklerini değerlendirebilmek amaciyla TA.XTPlus Tekstür Analiz cihazına (Stable Micro Systems, Godalming, Surrey, UK) bağlı bir Toz Akış Analiz cihazı (Stable Micro Systems) kullanılmıştır. Analizler için, Toz Akış Analiz cihazına 49.0 N kapasiteye sahip yük hücresi takılmıştır. Toz Akış Analiz sisteminde standart cam silindir (yüksekliği $120 \mathrm{~mm}$ ve iç çap1 $50 \mathrm{~mm} ; 220 \mathrm{~mL}$ toplam hacim) ve çap1 $48 \mathrm{~mm}$ ve yüksekliği $10 \mathrm{~mm}$ olan özel bir döner bıçak (Rotor no. R48/50/10/2/A) kullanılmıştır. Cihazın kuvvet (19.6 $\mathrm{N}$ kuvvet kullanarak) ve yükseklik kalibrasyonu (yükseklik ve hedef kalibrasyon diski kullanılarak) analiz öncesinde yapılmıştır. Her bir toz akış analizi için, süt tozu numunesi yaklaşık $140 \mathrm{~mL}$ hacim kaplayacak şekilde cam silindire konularak örnek miktarı tartılmıştır. Toz akış özelliklerini belirlemek için, şartlandırma döngüsünden sonra örneklere kekleşme analizi, kohezyon analizi, dört hızda kohezyon analizi ve hıza bağlı toz akış özellikleri (PFSD) analizi uygulanmıştır (Mercan ve ark., 2018). $\mathrm{Bu}$ analizlerin sonuçları Exponent yazılımı (Ver. 6.1.13.0, Stable Micro Systems) kullanılarak değerlendirilmiştir.

Kekleşme analizinde, biçak toz kolonunun tepe noktasını belirlemek ve kolon yüksekliğini ölçmek için $20 \mathrm{~mm} \mathrm{~s}^{-1}$ hız ve $2^{\circ}$ açıyla $49 \mathrm{mN}$ kuvvete kadar toz kolonuna sıkıştırma uygulamıştır. $\mathrm{Bu}$ işlemin ardından bıçak $20 \mathrm{~mm} \mathrm{~s}^{-1}$ hız ve $20^{\circ}$ açıyla toz kolonundan aşağıya doğru hareket ederek kek oluşturması için önceden belirlenen $7.35 \mathrm{~N}$ kuvvete ulaşıncaya kadar süt tozuna sıkıştırma uygulamıştır. Bıçak, hedef kuvvete $(7.35 \mathrm{~N})$ ulaşınca oluşan kek yüksekliğini belirlemiş ve $10 \mathrm{~mm} \mathrm{~s}^{-1}$ hiz ve $45^{\circ}$ açıyla toza yukarı doğru dilimleme hareketi uygulamıştır. $\mathrm{Bu}$ sıkıştırma döngüsü toplamda beş defa tekrarlanmıştır. Kekleşme analizi sonuçları, oluşan keki kesmek için gereken kuvvet olan kekleşme kuvveti (N.mm) ve oluşan keki gram cinsinden kesmek için ortalama kuvvet olan ortalama kekleşme kuvveti (N) olarak ifade edilmiştir. Ayrica her döngü için kek yükseklik oranı, mevcut döngünün toz kek yüksekliğinin başlangıçtaki kolon yüksekliğine bölünmesiyle hesaplanmıştır. 
Süt tozlarının kohezyon özellikleri bıçağın 50 $\mathrm{mm} \mathrm{s}^{-1}$ hız ve $170^{\circ}$ açıyla toz kolonundan aşağ 1 yönlü hareketi ve sonrasında $50 \mathrm{~mm} \mathrm{~s}^{-1}$ hız ve $178^{\circ}$ açıyla toz kolonundan yukarı doğru hareketten oluşan kohezyon analiziyle saptanmıștır. Elde edilen kuvvetkonum grafiğinin negatif alanından kohezyon katsayısı (N.mm) belirlenmiştir. Kohezyon indeksi, kohezyon katsayısının numune ağırlığına bölünmesi ile hesaplanmıştır. Kohezyon indeksine bağlı olarak tozların akış özelliklerindeki sıralama şu şekildedir: >19: aşırı derecede kohezif; 16-19: çok kohezif; 14 16: kohezif; 11-14: kolay akabilir; <11: serbest akabilir (Benković, Srečec, Špoljarić, Mršić ve Bauman, 2013). Ayrica kohezyon indeksi dört farklı hızda $\left(10,20,50\right.$ ve $\left.100 \mathrm{~mm} \mathrm{~s}^{-1}\right)$ belirlenmiştir. Tozların akış özelliklerini akış hızına göre değerlendirmek için PFSD analizi gerçekleștirilmiștir. PFSD analizinin sonuçları 10, 20, $50,100 \mathrm{~mm} \mathrm{~s}^{-1}$ de sıkıştırma katsayıları ve akış stabilitesi olarak verilmiştir.

\section{Partikül boyutu ölçümü}

Süt tozu numunelerinin partikül boyutu ölçümü, toz besleme ünitesine (Aero M, Malvern Instruments Ltd.) bağlı lazer kırınımı partikül boyutu analiz cihazı (Mastersizer 3000, Malvern Instruments Ltd., Worcestershire, İngiltere) kullanılarak kuru yöntemle gerçekleştirilmiştir. Tozun partikül boyutu ölçümünde numune herhangi bir işlem yapılmadan besleyiciye verilmiştir. Ölçüm koşulları şu şekilde uygulanmıștır: kırılma indisi, 1.54; hava basıncı, 2 bar ve besleme hızı, \%25. Mie teorisine bağlı olarak, partikül boyutu analizi sonuçları şu şekilde ifade verilmiştir: span, açıklık, D[4,3] = hacim ağırlıklı ortalama çap; $\mathrm{D}[3,2]$ = yüzey ağırlıklı alanı ortalama çap; $\mathrm{d}(0.1), \mathrm{d}(0.5)$ ve d(0.9) (Er ve ark., 2019).

\section{İstatistiksel Analiz}

Araştırma sonucu elde edilen verileri analiz etmek için Minitab 18 yazılımı (Minitab LLC, State College, PA) kullanılarak tek yön ANOVA analizi yapılmıştır. Süt tozlarının üretimi ve analizleri üç tekerrülü olarak yapılmıştır. Analizler üç parallelli olarak çalış1lmıştır.

\section{TARTIŞMA VE SONUÇ Fizikokimyasal Özellikler}

Tablo 1'de yağsız ve yağlı keçi süt tozlarının fizikokimyasal özellikleri verilmiștir. Yağsız örneklerin nem içeriğinin yağlı örneklere kıyasla daha yüksek olduğu belirlenmiştir $(\mathrm{P}<0.01)$. Bununla birlikte, her iki örneğin nem içeriğinin de $\% 5$ 'in altındadır. Bu durum, süt tozlarının Türk Gıda Kodeksi (TGK) Koyulaştırılmış Süt ve Süt Tozu Tebliği tarafindan bildirilen maksimum $\% 5$ nem içeriği standardına uygunluğunu göstermektedir (TGK, 2005). Nem oranının \%5'in üzerine çıkması ile Maillard Rekasiyonu hizlanmakta, protein denatürasyonu gerçekleşmekte ve laktoz kristalizayon hiz1 artmaktadır (Carić, 1994; Rosenthal, 1991). Bu kapsamda üretilen keçi sütü tozları belirtilen özellikler bakımından güvenli sayılabilir. Yağsız ve yağlı süt tozlarının yağ içeriği sirasiyla $\% 0.5$ ve $\% 30$ olarak bulunmuştur. TGK'ye göre yağ miktarı yağsız süt tozu için $\leq \% 1.5$, tam yağl1 için ise \%26-42'dir (TGK, 2005). Üretilen keçi süt tozlarının yasal kriterleri karşıladığ 1 görülmektedir.

Yağsız keçi sütü tozunun protein oran1 $\% 36.75$, yağlı süt tozununki ise \%25.90'dır. ADPI standartları yağsız süt tozlarının minimum $\% 34$ protein içeriğine sahip olması gerektiğini bildirmektedir (ADPI, 2018a). Örneklerin kül içeriği \%6.40-7.39 arasında değişirken, yağsız süt tozunun kül içeriği yağlı süt tozuna kıyasla daha yüksek bulunmuştur $(\mathrm{P}<0.01)$. Önceki çalışmalarda yağsız inek sütü tozlarında kül oranı \%7.40-7.82 aralığında bulunmuștur (Schuck, Jeantet ve Dolivet, 2012; Sert, Mercan, Aydemir ve Civelek, 2016). İstatistiki analiz sonuçlarına göre, süt tozların yağ içeriğinin $\mathrm{pH}$ ve titrasyon asitliğini etkilemediği belirlenmiştir $(\mathrm{P}>0.05)$. Yapılan bir çalışmada, Osmanabadi yağlı keçi sütü tozunun $\% 4.08$ nem içeriği, \%26.85 yağ, \%25.48 protein, $\% 6.6$ kül ve 0.14 \%LA titre edilebilir asitlik değerlerine sahip olduğu bildirilmiștir (Reddy ve ark., 2014). S1kıştırılmış yığın yoğunluğu yağsız örnekte $0.71 \mathrm{~g} \mathrm{~cm}^{-3}$, yağl1 örnekte $0.57 \mathrm{~g} \mathrm{~cm}^{-3}$ olarak belirlenmiştir. 
Tablo 1. Keçi süt tozlarının fizikokimyasal özellikleri

\begin{tabular}{|c|c|c|c|c|c|c|c|c|}
\hline Örnek & $\begin{array}{l}\text { Nem } \\
(\%)\end{array}$ & $\begin{array}{l}\text { Yağ } \\
(\%)\end{array}$ & $\begin{array}{c}\text { Protein } \\
(\%)\end{array}$ & $\begin{array}{l}\text { Kül } \\
(\%)\end{array}$ & $\begin{array}{l}\text { Asitlik } \\
\text { (\%LA) }\end{array}$ & $\mathrm{pH}$ & $\begin{array}{c}\text { Sikıştırılmış } \\
\text { y1 ğın } \\
\text { yoğunluğu } \\
\left(\mathrm{g} \mathrm{cm}^{-3}\right)\end{array}$ & $\begin{array}{c}\text { Çözünebilirlik } \\
(\%)\end{array}$ \\
\hline Yağsız & $3.77 \pm 0.04$ & $0.5 \pm 0.0$ & $36.75 \pm 0.11$ & $7.39 \pm 0.08$ & $0.15 \pm 0.01$ & $6.60 \pm 0.02$ & $0.71 \pm 0.01$ & $99.8 \pm 0.0$ \\
\hline Yağlı & $3.17 \pm 0.05$ & $30.0 \pm 0.0$ & $25.90 \pm 0.08$ & $6.40 \pm 0.06$ & $0.11 \pm 0.00$ & $6.69 \pm 0.02$ & $0.57 \pm 0.01$ & $99.8 \pm 0.0$ \\
\hline$P$ & $* *$ & $* *$ & $* *$ & $* *$ & ns & ns & $* *$ & ns \\
\hline
\end{tabular}

Farklı besleme sıcaklığ 1 ve konsantrasyonlarına göre, yağlı keçi süt tozlarında sıkıştırılmış yığın yoğunluğunun $0.41-0.58 \mathrm{~g} \mathrm{~cm}^{-3}$ aralı̆̆ında değiştiğ i bildirilmiştir (Reddy ve ark., 2014).Yağsiz ve yağlı numunelerde çözünebilirlik oranı \%99.80'dir. ADPI standartları yağsız ve yağlı süt tozlarında minimum \%99 çözünebilirlik oranı istemektedir (ADPI, 2018a, 2018b). Bu çalışmada keçi süt tozlarındaki çözünebilirlik oranlarının ilgili standartlara uygun olduğu belirlenmiştir

\section{Toz Akış Özellikleri}

Bir tozun depolanması ve nakliyesi sırasında büyük topaklar oluşturma eğilimine kekleşme adı verilmektedir. Kekleşme sırasında oluşan yapılar küçük ve yumuşak agregalardan sert ve büyük topaklara kadar değişebilmekte ve bu yapılar toz ürünlerde akışkanlık kaybına neden olmaktadır. Süt tozlarının kekleşmeye karşı duyarlılığı, toz akış özellikleri hakkında önemli bilgiler verebilmektedir (Mercan ve ark., 2018).

Yağsız ve yağlı keçi süt tozlarının kekleşme kuvveti ve ortalama kekleşme kuvveti değerleri Tablo 2'de gösterilmiştir. Yağsız toz örneğinin kekleşme kuvveti ve ortalama kekleşme kuvveti değerleri sirasıyla $-0.190 \quad$ N.mm ve $-0.551 \quad \mathrm{~N}$ olarak bulunmuştur. Bir diğer ifadeyle, yağsız keçi süt tozlarında kekleşme oluşmamıştır. Keçi süt tozlarında yağ içeriği bu değerleri önemli ölçüde arttırmış olup, yağlı süt tozlarında bu değerler 26.734 N.mm ve
1.702 N'dur. Yapılan bir çalışmada, bu değerlerin yağsız inek süt tozu için $1.26 \mathrm{~N} . \mathrm{mm}$ ve $0.13 \mathrm{~N}$ olduğu bildirilmiştir (Er ve ark., 2019). Yağsız süt tozları genellikle serbest akış özelliği göstermektedir. Bununla birlikte, depolama, işleme veya nakliye sırasında serbest akış özelliğini kaybedebilirler. Bu durum genellikle kek oluşumundan kaynaklanmaktadır. Bu nedenle süt tozlarında kek oluşumu süt endüstrisinde önemli bir sorundur (Mercan ve ark., 2018).

Kekleşme analizi boyunca yağsız ve yağlı keçi süt tozlarının her döngüdeki kek yükseklik oranları Şekil 1'de verilmiştir. Yağsız örnekte döngü sayısına bağlı olarak kek yükseklik oranlarında önemli bir değişiklik olmadığı ve neredeyse aynı düzeyde kaldığ 1 belirlenmiştir. Yağlı süt tozunda ise 1 . döngüde 0.156 düzeyinde olan kek yükseklik oranının 5. döngüde 0.341 düzeyine çıtı̆̆ 1 görülmektedir. Görülen bu artış örneğin kekleşmeye eğilimli olduğunu göstermektedir ve bu durum Tablo 2'de verilen kekleşme kuvveti ve ortalama kekleşme kuvveti değerleri ile uyumludur. Kek yükseklik oranındaki keskin artışların, toz numunenin kek oluşumuna karşı yüksek duyarlılığa sahip olduğunu göstermektedir (Benković, Belščak-Cvitanović, Bauman, Komes ve Srečec, 2017). Yağlı inek süt tozunun kek yükseklik oranında döngüye bağlı artışın olduğu daha önce yapılan bir çalışma tarafindan da bildirilmiştir (Göksel-Saraç, Türker ve Doğan, 2021). 
Tablo 2. Keçi süt tozlarının kekleşme ve ortalama kekleşme kuvveti değerleri

\begin{tabular}{|c|c|c|}
\hline Örnek & $\begin{array}{l}\text { Kekleşme kuvveti } \\
\text { (N.mm) }\end{array}$ & $\begin{array}{l}\text { Ortalama kekleşme kuvveti } \\
\qquad(\mathrm{N})\end{array}$ \\
\hline Yağsız & $-0.190 \pm 0.001$ & $-0.551 \pm 0.002$ \\
\hline \multirow[t]{2}{*}{ Yağlı } & $26.734 \pm 0.376$ & $1.702 \pm 0.040$ \\
\hline & $* *$ & $* *$ \\
\hline
\end{tabular}
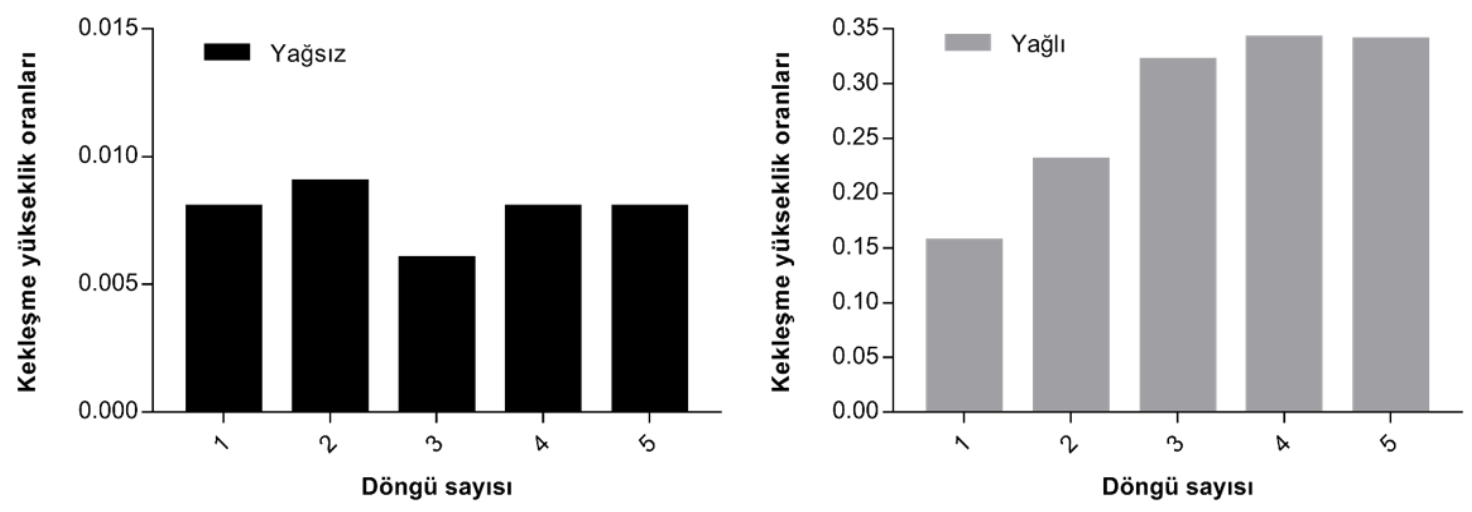

Şekil 1. Keçi süt tozlarının kek yükseklik oranları

Toz partikülleri birbirine tutunma ve daha büyük partikül kümeleri oluşturma eğilimine koheziflik denmektedir (Mercan ve ark., 2018). Tablo 3'de, yağsız ve yağlı keçi süt tozlarının kohezyon katsayısı, kohezyon indeksi ve dört farklı hizda $(10,20,50$ ve $100 \mathrm{~mm} \mathrm{~s}^{-1}$ ) kohezyon indeksleri verilmiştir. Yağlı süt tozunun kohezyon katsayısının yağsız örneğe kıyasla daha düşük olduğu görülmektedir. Kohezyon katsayısındaki düşüş yani negatif yöndeki artış örneğin kohezif özelliğinin arttığını belirtmektedir. Tozların kalite kontrolünde, kohezyon indeksi değeri numune ağırlığının etkisini ortadan kaldırması nedeniyle oldukça kullanışlı bir yöntemdir. Süt tozu numunesinin kohezyonu indeksi değeri ve akışkanlığı arasında ters bir ilişki bulunmaktadır (Mercan, 2019). Yağsız süt tozu örneğinin kohezyon indeksi değeri 21.7 iken yağl1 örneğin kohezyon indeksi değeri 42.2 olarak bulunmuştur. Örnekler arasında iki kata yakın fark bulunmasina rağmen, kohezyon indeksine bağlı olarak akıș sınıflandırmasına göre her iki örneğin de aşırı kohezif akış özelliğine sahip olduğu görülmektedir (Benković, Srečec, ve ark., 2013). Toz akış analiz cihazı ile elde edilen yağsız inek süt tozu kohezyon indeksi değerlerinin 10.11-13.56 aralığında değiştiği bildirilmektedir (Bansal, Premi, Sharma ve Nanda, 2017; Benković, Srečec, ve ark., 2013). Bu sonuçlara göre, keçi süt tozlarının inek sütünden elde edilenlere kıyasla daha kohezif özellik gösterdiği tespit edilmiştir. Kohezyonu, elektrostatik aktivite, partikül boyutu ve şekli, gözeneklilik ve higroskopiklik gibi çok sayıda fiziksel parametrenin etkilediği bildirilmektedir (Thomas, Scher, DesobryBanon ve Desobry, 2004). 
Tablo 3. Keçi süt tozlarının kohezyon katsayısı, kohezyon indeksi ve dört hızda kohezyon indeksi değerleri

\begin{tabular}{|c|c|c|c|c|c|c|}
\hline \multirow[b]{2}{*}{ Örnek } & \multirow[b]{2}{*}{$\begin{array}{c}\text { Kohezyon } \\
\text { Katsayis1 } \\
\text { (N.mm) }\end{array}$} & \multirow[b]{2}{*}{$\begin{array}{c}\text { Kohezyon } \\
\text { indeksi }\end{array}$} & \multicolumn{4}{|c|}{ Dört Hizda Kohezyon İndeksi } \\
\hline & & & $10 \mathrm{~mm} \mathrm{~s}^{-1}$ & $20 \mathrm{~mm} \mathrm{~s}^{-1}$ & $50 \mathrm{~mm} \mathrm{~s}^{-1}$ & $100 \mathrm{~mm} \mathrm{~s}^{-1}$ \\
\hline Yağsız & $-11.7 \pm 0.4$ & $21.7 \pm 0.4$ & $24.9 \pm 0.2$ & $27.0 \pm 0.1$ & $28.2 \pm 0.3$ & $28.3 \pm 0.4$ \\
\hline Yağlı & $-23.1 \pm 1.3$ & $42.2 \pm 0.6$ & $52.8 \pm 0.3$ & $50.8 \pm 0.2$ & $54.8 \pm 0.2$ & $51.8 \pm 0.2$ \\
\hline$P$ & $* *$ & $* *$ & $* *$ & $* *$ & $* *$ & $* *$ \\
\hline
\end{tabular}

Dört hızda kohezyon analizi, süt tozlarının akış hızına bağlı olarak toz akış davranışlarını belirlemektedir. $\mathrm{Bu}$ analiz, toz numunelerinin dört farklı akış hızından oluşan kontrollü akışa karşı direncini ölçmektedir. Süt endüstrisinde, süt tozlarının nakliyesi ve işlenmesi sırasındaki bazı koşulları simüle etmesi nedeniyle süt tozlarının kohezyon indeksinde 10, 20, 50 ve $100 \mathrm{~mm} \mathrm{~s}^{-1}$ akış hızları kullanılmışırır (Mercan ve ark., 2018). Yağsız keçi sütü tozlarının dört farklı hızda kohezyon indeksi değerleri 24.9-28.3 arasında değişirken, bu değer yağlı örnekler için 50.8-54.8 aralığında bulunmuştur. Yağsız örneklerin artan akış hızına bağlı olarak kohezyon indeksi değerlerinin arttığı yani akış özelliğinin azaldığı tespit edilmiştir. Yağlı örnek için en kolay taşıma hızının $20 \mathrm{~mm} \mathrm{~s}^{-1}$ olduğu belirlenmiştir. Farklı yağ içeriğine sahip örnekler tüm akış hızlarında aşırı kohezif akış davranışı göstermiştir. Ancak, yağlı örneklerinin kohezyon indeksi değerlerinin yağsız örneklere kıyasla oldukça yüksek olduğu belirlenmiştir $(\mathrm{P}<0.01)$.

$\mathrm{Bu}$ çalışmada yapılan tüm kohezyon analizi sonuçlarına göre, yağlı keçi süt tozlarının kohezifliğinin yağsız süt tozlarına kıyasla oldukça yüksek olduğu saptanmıştır. Diğer bir ifadeyle yağsız süt tozlarının akabilirliğinin daha yüksek olduğu tespit edilmiştir. $\mathrm{Bu}$ durumun sebebi yağsiz süt tozlarının yüzeyinin büyük çoğunlukla laktoz ve protein ile az miktarda yağdan oluşmasıdır. Bununla birlikte yağlı süt tozlarının yüksek yüzey yağı akmayı inhibe etmektedir. Ayrıca tozların yüzeyindeki yağ, partiküllerin birbirine yapışmasına veya aglomere olmasına neden olarak tozların akışkanlığını bozmaktadır (Kim, Chen ve Pearce, 2005).
Artan veya azalan akış hızları toz akış özelliklerini etkileyebilmektedir. Toz bir ürün daha hızlı akmaya zorlandığında akmaya direnç gösterebilmekte veya akış hızı arttığında daha kolay akabilir olmaktadır (Mercan, 2019). Süt tozlarının farklı hızlardaki kontrollü akışa karşı direncinin ölçmek için hıza bağlı toz akış özellikleri (PFSD) analizi yapılmıştır. Seçilen hızlar, süt tozlarının taşınması ve işlenmesi esnasında meydana gelebilecek farklı durumların simüle edilmesi amacıyla belirlenmiştir. PFSD analizi sonucunda artan analiz hızlarındaki sıkıştırma katsayıları ve akış stabilitesi değerleri Tablo 4'de verilmiştir. PFSD analizinde her sıkıştırma döngüsünde elde edilen kuvvet/mesafe grafiklerinin altında kalan pozitif alandan sıkıştırma katsayıları hesaplanmaktadır (Göksel Saraç, 2018). Artan hıza bağlı olarak farklı hızlardaki sıkıştırma katsayısı değerleri yağsız örnek için 38.6-50.0 N.mm aralığında, yağlı örnek için ise 63.3-73.6 N.mm aralığında tespit edilmiştir. Akış hızına bağlı olarak, yağlı ve yağsız keçi süt tozlarının sıkıştırma katsayılarında değişim gözlenmiştir. Her iki numunenin de sıkıştırma katsayısı değerleri artan analiz hızına bağlı olarak azalma göstermiş olup en düşük sıkıştırma katsayısı değerleri $100 \mathrm{~mm} \mathrm{~s}^{-1}$ analiz hızında belirlenmiştir. Bu durum, yağsız ve yağlı keçi süt tozu numunelerinin yüksek akış hızlarında daha az direnç gösterdiğinin bir göstergesidir. Önceki bir çalışmada, azalan sıkıştırma katsayısına bağlı olarak toz ürünlerin yüksek hızlarda daha kolay taşınabileceğini belirtilmiştir (Benković, BelščakCvitanović, Komes ve Bauman, 2013). 
Tablo 4. Keçi süt tozlarının hıza bağlı toz akış özellikleri

\begin{tabular}{|c|c|c|c|c|c|}
\hline \multirow[b]{2}{*}{ Örnek } & \multicolumn{4}{|c|}{ Sıkıştırma katsayısı (N.mm) } & \multirow[b]{2}{*}{ Akış stabilitesi } \\
\hline & $10 \mathrm{~mm} \mathrm{~s}^{-1}$ & $20 \mathrm{~mm} \mathrm{~s}^{-1}$ & $50 \mathrm{~mm} \mathrm{~s}^{-1}$ & $100 \mathrm{~mm} \mathrm{~s}^{-1}$ & \\
\hline Yağs1z & $50.0 \pm 0.3$ & $49.9 \pm 1.6$ & $46.7 \pm 0.5$ & $38.6 \pm 0.6$ & $1.18 \pm 0.03$ \\
\hline \multirow[t]{2}{*}{ Yağl1 } & $73.6 \pm 1.3$ & $72.6 \pm 1.3$ & $71.5 \pm 2.2$ & $63.3 \pm 1.8$ & $1.03 \pm 0.01$ \\
\hline & $* *$ & $* *$ & $* *$ & $* *$ & $*$ \\
\hline
\end{tabular}

PFSD analizinde elde edilen bir diğer parametre olan akış stabilitesi değeri yağsız örnek için 1.18 iken yağl1 örnek için 1.03 'tür. Örneklerin yağ içeriğinin akış stabilitesine etkisi önemli düzeyde bulunmuştur $(\mathrm{P}<0.05)$. Akış stabilitesi 1.00'e yakın olduğunda, analiz süresince süt tozunun önemli ölçüde değişmediğini göstermektedir (Benković, BelščakCvitanović, ve ark., 2013). Akış stabilitesi değeri, toz ürünlerde akış direncine dair önemli bilgi vermektedir (Göksel-Saraç ve ark., 2021). Akış stabilitesindeki değişmeler, kümelerin parçalanması veya süt tozu partiküllerinin aşınmasıyla ilgili olabilmektedir (Mercan ve ark., 2018).

\section{Partikül Boyutu Parametreleri}

Yağsız ve yağlı keçi süt tozlarının partikül boyutu parametreleri Tablo 5'de verilmiştir. Partikül boyutu ölçümü sonuçları span, D[3,2], D[4,3], d(0.1), $\mathrm{d}(0.5)$ ve $\mathrm{d}(0.9)$ değerleri olmak üzere 6 farklı parametre ile değerlendirilmiştir. Span, partikül dağılımının genişliğini gösteren bir değerdir. Kurutma esnasında oluşan partikül boyut dağılımı ve partiküller arası ilişki tozun akabilme yeteneğini etkilemektedir. Örneklerin span değerleri 1.81-2.26 aralığında değişirken yağsız süt tozunun daha yüksek span değerine sahip olduğu belirlenmiştir $(\mathrm{P}<0.05)$. Yapılan bir çalışmada span değerinin yağsız süt tozunda 1.93 olduğu tespit edilmiştir (Ilari ve Mekkaoui, 2005).

$D[4,3]$ hacim ağırlıklı ortalama olarak da ifade edilmektedir ve çoğunluka partikül sayısının önemsiz olduğu durumlarda tercih edilmektedir. Yağsız keçi süt tozunda $\mathrm{D}[4,3]$ değeri $44.0 \mu \mathrm{m}$, yağlı örnekte ise
$34.2 \mu \mathrm{m}$ olarak tespit edilmiştir. D[3,2] aynı zamanda yüzey ağırlıklı ortalama olarak da bilinmektedir. Sauter ortalama çap1 olarak da tanımlanan D[3,2] değeri aktif yüzeylere sahip veya yüzey alanının öneme sahip olduğu hallerde tercih edilmektedir. Örneklerin $\mathrm{D}[3,2]$ değerleri 23.6-25.2 $\mu \mathrm{m}$ arasında bulunmuştur. Bu değerin yağsız örnekte yağlı örneğe kıyasla daha yüksek olduğu belirlenmiştir. Sert ve ark. (2016) yağsız inek süt tozlarında D[3,2] 14.07$24.91 \mu \mathrm{m}$ arasinda bulurken Pugliese ve ark. (2017) bu değeri 25.86-60.79 $\mu \mathrm{m}$ olarak bildirmiştir.

$\mathrm{d}(0.1)$ değeri örneğin \%10'unun bu çapın altında olduğunu göstermektedir. Örneklerin $\mathrm{d}(0.1)$ değeri 12.1-13.7 $\mu \mathrm{m}$ aralığında değişmiştir. $\mathrm{d}(0.5)$ değeri numunenin \%50'sinin bu çapın altında olduğunu ifade etmektedir. Yağsiz süt tozunun $\mathrm{d}(0.5)$ değeri $34.5 \mu \mathrm{m}$, yağlı örneğin ise $26.8 \mu \mathrm{m}$ 'dir. Ilari ve Mekkaoui (2005) tarafindan yağsız inek süt tozlarında bu değer $66 \mu \mathrm{m}$ olarak bildirmiştir. Nikolova ve ark. (2014) ise $\mathrm{d}(0.5)$ değerinin 51.1$123.7 \mu \mathrm{m}$ aralığında değiştiğini belirtmiştir. Lesitin ilave edilerek üretilen keçi süt tozlarında ise $d(0.5)$ değerinin 1-15 aralığında olduğu bildirilmiştir (Fonseca ve ark., 2011). d(0.9) değeri örneğin \%90'ının bu çapın altında olduğunu göstermektedir. Örneklerin $\mathrm{d}(0.9)$ değerleri 62.2-90.1 $\mu \mathrm{m}$ aralı̆̆ında bulunmuştur. Yağsız süt tozunda $d(0.5)$ ve $d(0.9)$ değerlerinin yağlı örneğe kıyasla daha yüksek olduğu belirlenmiştir. Yağsız ve yağlı keçi süt tozlarının partikül boyutu dağılım grafikleri Şekil 2'de verilmiştir. Örnekler monomodal partikül dağılımı yani tek pik göstermiştir. 
Tablo 5. Keçi süt tozlarının partikül boyutu değerleri

\begin{tabular}{|c|c|c|c|c|c|c|}
\hline Örnek & Span & $\begin{array}{c}\mathrm{D}[4,3] \\
(\mu \mathrm{m})\end{array}$ & $\begin{array}{c}\mathrm{D}[3,2] \\
(\mu \mathrm{m})\end{array}$ & $\begin{array}{c}\mathrm{d}(0.1) \\
(\mu \mathrm{m})\end{array}$ & $\begin{array}{c}\mathrm{d}(0.5) \\
(\mu \mathrm{m})\end{array}$ & $\begin{array}{r}\mathrm{d}(0.9) \\
(\mu \mathrm{m})\end{array}$ \\
\hline Yağs1z & $2.26 \pm 0.01$ & $44.0 \pm 0.5$ & $25.2 \pm 0.1$ & $12.1 \pm 0.0$ & $34.5 \pm 0.3$ & $90.1 \pm 1.1$ \\
\hline Yağl1 & $1.81 \pm 0.00$ & $34.2 \pm 0.0$ & $23.6 \pm 0.0$ & $13.7 \pm 0.0$ & $26.8 \pm 0.0$ & $62.2 \pm 0.0$ \\
\hline$P$ & $* *$ & $* *$ & $* *$ & $* *$ & $* *$ & $* *$ \\
\hline
\end{tabular}

$\bar{X} \pm$ standart sapma, $\mathrm{n}=3$

$* P<0.05 ; * * P<0.01$; ns, istatistiki açıdan önemsiz

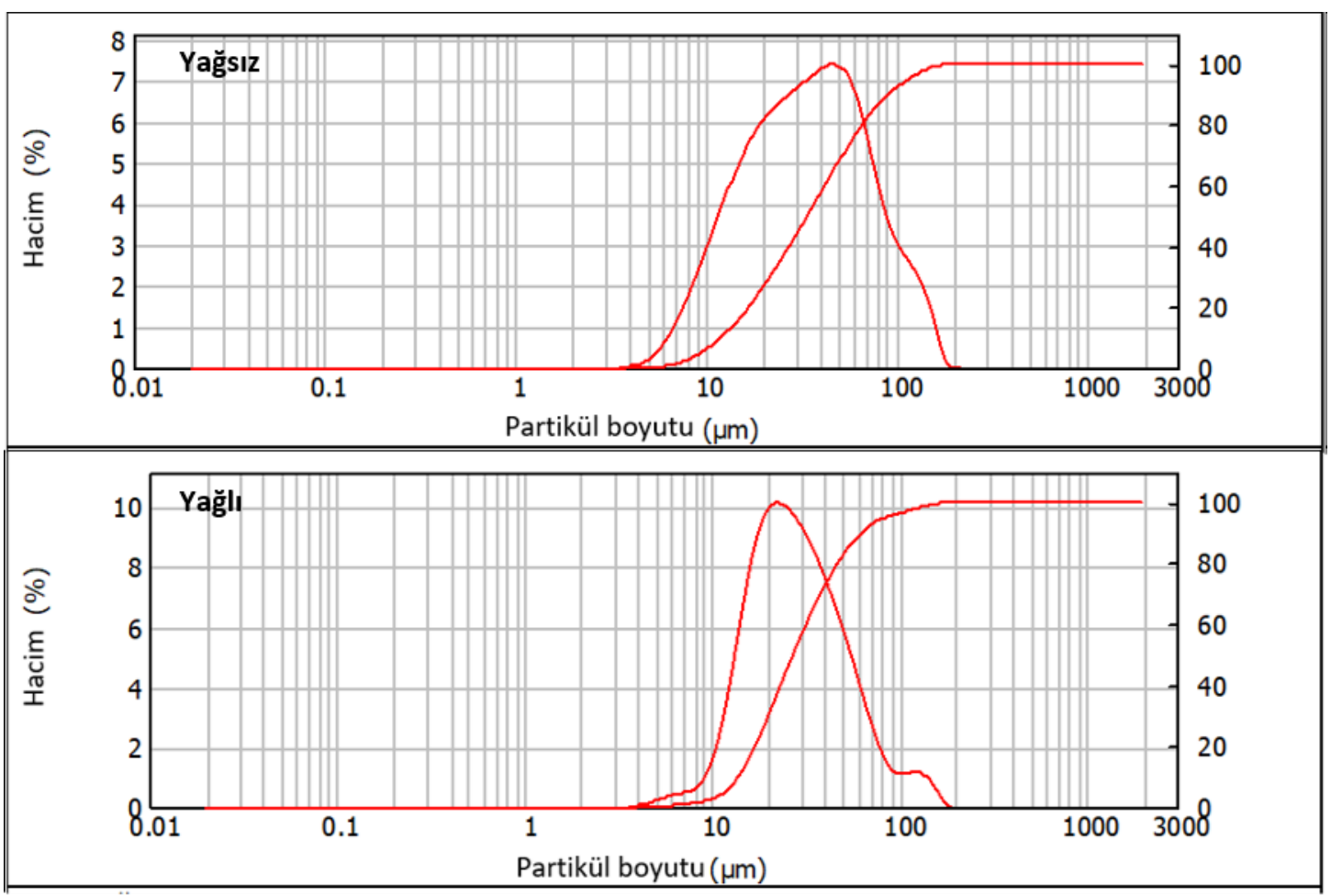

Şekil 2. Keçi süt tozlarının partikül boyutu dağılım grafikleri

Her iki örneğin de partikül dağılımları genel olarak 4-200 $\mu \mathrm{m}$ aralığında bulunmuştur. Aynı aralıkta dağılım gözükse de hacim bakımından yağsız süt tozlarının dağılımının daha geniş olduğu grafikten anlaşılmaktadır.

$\mathrm{Bu}$ durum örneklerin span değerleriyle uyumludur. Yağsiz ve yağlı örneklerin $100 \mu$ m'den sonra omuz verdiği görülmüştür. Turchiuli, Smail ve Dumoulin (2013) yağsız inek süt tozlarında monomodal dağılım ve dağılımın pik noktasının 100 $\mu$ m'den yüksek olduğunu belirtmiş olup bu durum mevcut çalışmaya kıyasla daha yüksektir. Ayrıca aglomerasyon süresine bağlı olarak partikül dağılım grafiğinin değişebildiği ve bazı durumlarda partikül dağılım eğrisinde omuz verme görüldüğü belirtilmiştir.

\section{SONUÇAR}

Bu çalışmada, püskürterek kurutulmuş yağsız ve yağlı keçi sütü tozlarının bazı fizikokimyasal 
özellikleri, toz akıș davranıșları (kekleșme, kohezyon ve hıza bağlı toz akış özellikleri) ve partikül boyutu parametreleri incelenmiştir. Yağsiz süt tozunun sıkıştırılmış yığın yoğunluğu, nem, protein ve kül içeriğinin yağlıya kıyasla daha yüksek olduğu belirlenmiştir. Yağsız süt tozuna kıyasla, yağlı süt tozlarında kekleşmeye yatkınlığın ve kohezifliğin arttığı görülmüştür. Hıza bağlı toz akış analizi sonuçlarına göre, artan taşıma hızlarında her iki örneğinde daha kolay taşınabileceği belirlenmiştir. Bununla birlikte, yağsız süt tozlarının artan hıza bağlı sıkıştırma katsayıları yağlı süt tozlarına göre oldukça düşük bulunmuştur. Toz akış analizi neticesinde, yağsız süt tozlarının depolama ile daha zor

\section{KAYNAKLAR}

ADPI. (2002). Standards for grades of dry milks including methods of analysis. . In Dry Milks (Bulletin No 916). Elmhurst, IL: American Dairy Products Institute.

ADPI. (2018a). Skim Milk Powder (SMP) Standard. In Dry Milks. Elmhurst, IL: American Dairy Products Institute.

ADPI. (2018b). Whole Milk Powder (WMP) Standard. In Dry Milks. Elmhurst, IL: American Dairy Products Institute.

Bansal, V., Premi, M., Sharma, H. K.ve Nanda, V. (2017). Compositional, physical, functional attributes and flow characterization of spray-dried skim milk powder enriched with honey. Journal of Food Measurement and Characterization, 11(3), 14741485.

Baykal, H., Karais, K., Çalışkan-Koç, G.ve Dirim, S. N. (2018). Tarçın, keçiboynuzu ve zencefil ile zenginleştirilerek üretilmiş keçi sütü tozlarının özellikleri. Glda, 43(4), 716-732.

Benković, M., Belščak-Cvitanović, A., Bauman, I., Komes, D.ve Srečec, S. (2017). Flow properties and chemical composition of carob (Ceratonia siliqua L.) flours as related to particle size and seed presence. Food Research International, 100, 211-218.

Benković, M., Belščak-Cvitanović, A., Komes, D.ve Bauman, I. (2013). Physical properties of nonagglomerated cocoa drink powder mixtures containing various types of sugar and sweetener. Food and Bioprocess Technology, 6(4), 1044-1058.

Benković, M., Srečec, S., Špoljarić, I., Mršić, G.ve Bauman, I. (2013). Flow Properties of Commonly Used Food Powders and Their Mixtures. Food and Bioprocess Technology, 6(9), 2525-2537.: https://doi.org/10.1007/s11947-012-0925-3

Carić, M. (1994). Concentrated and dried dairy products. New York, USA: VCH Publisher.

Er, B., Sert, D.ve Mercan, E. (2019). Production of skim milk powder by spray-drying from transglutaminase kekleşeceği, daha düşük koheziflik ve sıkıştırma katsayıları ile toz ürün formülasyonu ve taşıma gibi durumlarda yağlı süt tozuna kıyasla daha işlenebilir olduğu tespit edilmiştir. Bu çalışmada, ticari öneme sahip keçi süt tozlarının toz akış özelliklerinin karakterizasyonun literatür açısından önemli olduğu sonucuna varılmıştır. Elde edilen sonuçların ileride yapılacak olan çalışmalarda, keçi süt tozlarının farklı işleme koşullarında üretilmesi ve farklı sıcaklıklarda depolanmasında meydana gelen değişikliklerin incelenmesi açısından yol gösterici olacağı düşünülmektedir.

treated milk concentrates: Effects on physicochemical, powder flow, thermal and microstructural characteristics. International Dairy Journal, 99, 104544. https://doi.org/10.1016/j.idairyj.2019.104544

Fonseca, C. R., Bento, M. S. G., Quintero, E. S. M., Gabas, A. L.ve Oliveira, C. A. F. (2011). Physical properties of goat milk powder with soy lecithin added before spray drying. International Journal of Food Science \& Technology, 46(3), 608-611. https://doi.org/10.1111/j.1365-2621.2010.02527.x

GEA. (2004). A 25 a - ash content. In Analytical Methods for Dry Milk Products (GEA Niro Method No. A 25 a). Copenhagen, Denmark: GEA Niro.

GEA. (2005). A 9 b - total fat by gerber/teichert. In Analytical Methods for Dry Milk Products (GEA Niro Method No. A 9 b). Copenhagen, Denmark: GEA Niro.

GEA. (2006a). A 1 b - powder moisture accurate standard method. In Analytical Methods for Dry Milk Products (GEA Niro Method No. A 1 b). Copenhagen, Denmark: GEA Niro.

GEA. (2006b). A 19 a - titratable acidity. In Analytical Methods for Dry Milk Products (Vol. GEA Niro Method No. A 19 a). Copenhagen, Denmark: GEA Niro.

Göksel-Saraç, M., Türker, D. A.ve Doğan, M. (2021). Ticari öneme sahip toz süt ürünlerinin morfolojik yapısı ve toz akış özelliklerinin belirlenmesi. Gıda, 46(1), 119-133.

Göksel Saraç, M. (2018). Rendering Artık Yağlarından Emülgatör Üretimi ve Model Gidalarda Arayüzey (interfacial) Reolojik Uygulamalarl. (Doktora Tezi). Erciyes Üniversitesi, Kayseri, Türkiye.

IDF. (1995). Dried milk and dried milk products determination of bulk density. In Dried Milk and Dried Milk Products (IDF standard 134A). Brussels, Belgium: International Dairy Federation. 
Ilari, J.-L.ve Mekkaoui, L. (2005). Physical properties of constitutive size classes of spray-dried skim milk powder and their mixtures. Le Lait, 85(4-5), 279-294.

Kim, E. H. J., Chen, X. D.ve Pearce, D. (2005). Effect of surface composition on the flowability of industrial spray-dried dairy powders. Colloids and Surfaces B: Biointerfaces, $\quad 46(3), \quad 182-187$. https://doi.org/10.1016/j.colsurfb.2005.11.005

Mercan, E. (2019). Yüksek basınç uygulanmış yağlı ve yağsız sütten üretilen süt tozlarının farkl sicaklıklarda depolanması süresince bazı fizikokimyasal özelliklerinin belirlenmesi. (Doktora Tezi). Selçuk Üniversitesi, Konya, Türkiye. (537958)

Mercan, E., Sert, D.ve Akın, N. (2018). Determination of powder flow properties of skim milk powder produced from high-pressure homogenization treated milk concentrates during storage. $L W T, 97,279-288$. doi:https://doi.org/10.1016/j.lwt.2018.07.002

Nikolova, Y., Petit, J., Sanders, C., Gianfrancesco, A., Desbenoit, N., Frache, G., . . Gaiani, C. (2014). Is it possible to modulate the structure of skim milk particle through drying process and parameters? Journal of Food Engineering, 142, 179-189.

Pandya, A.ve Ghodke, K. (2007). Goat and sheep milk products other than cheeses and yoghurt. Small Ruminant Research, 68(1-2), 193-206.

Pugliese, A., Cabassi, G., Chiavaro, E., Paciulli, M., Carini, E.ve Mucchetti, G. (2017). Physical characterization of whole and skim dried milk powders. Journal of Food Science and Technology, 54(11), 3433-3442. https://doi.org/10.1007/s13197017-2795-1

Pulina, G., Milán, M. J., Lavín, M. P., Theodoridis, A., Morin, E., Capote, J., . . . Caja, G. (2018). Invited review: Current production trends, farm structures, and economics of the dairy sheep and goat sectors. Journal of Dairy Science, 101(8), 6715-6729. https://doi.org/10.3168/jds.2017-14015

Ranadheera, C., Evans, C., Baines, S., Balthazar, C. F., Cruz, A. G., Esmerino, E. A., . . . Naumovski, N. (2019). Probiotics in goat milk products: Delivery capacity and ability to improve sensory attributes.
Comprehensive Reviews in Food Science and Food Safety, 18(4), 867-882.

Ranadheera, C. S., Naumovski, N.ve Ajlouni, S. (2018). Non-bovine milk products as emerging probiotic carriers: Recent developments and innovations. Current Opinion in Food Science, 22, 109-114.

Reddy, R. S., Ramachandra, C., Hiregoudar, S., Nidoni, U., Ram, J.ve Kammar, M. (2014). Influence of processing conditions on functional and reconstitution properties of milk powder made from Osmanabadi goat milk by spray drying. Small Ruminant Research, 119(1-3), 130-137.

Rosenthal, I. (1991). Milk and Dairy Products: Wiley.

Schuck, P., Jeantet, R.ve Dolivet, A. (2012). Analytical methods for food and dairy powders. Oxford, UK: John Wiley \& Sons.

Sert, D., Mercan, E., Aydemir, S.ve Civelek, M. (2016). Effects of milk somatic cell counts on some physicochemical and functional characteristics of skim and whole milk powders. Journal of Dairy Science, $\quad 99(7), \quad 5254-5264$. https://doi.org/10.3168/jds.2016-10860

Slačanac, V., Božanić, R., Hardi, J., Rezessyné Szabó, J., Lučan, i.ve Krstanović, V. (2010). Nutritional and therapeutic value of fermented caprine milk. International Journal of Dairy Technology, 63(2), 171-189. https://doi.org/10.1111/j.14710307.2010.00575.x

TGK. (2005). Türk Gıda Kodeksi Koyulaştırılmış Süt ve Süt Tozu Tebliği In Türk Glda Kodeksi Yönetmeliği (2005/18). Resmi Gazete, Ankara: Tarım ve Orman Bakanlığı.

Thomas, M. E. C., Scher, J., Desobry-Banon, S.ve Desobry, S. (2004). Milk Powders Ageing: Effect on Physical and Functional Properties. Critical Reviews in Food Science and Nutrition, 44(5), 297-322. https://doi.org/10.1080/10408690490464041

Turchiuli, C., Smail, R.ve Dumoulin, E. (2013). Fluidized bed agglomeration of skim milk powder: Analysis of sampling for the follow-up of agglomerate growth. Powder Technology, 238, 161-168. https://doi.org/10.1016/j.powtec.2012.02.030 